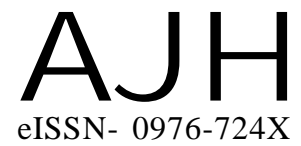

Received : 29.08.2017

Revised : 10.11.2017

Accepted : 17.11.2017

Members of the Research Forum

Associated Authors:

${ }^{1}$ Department of Horticulture,

Faculty of Agriculture,

Annamalai University,

ANNAMALAI NAGAR (T.N.)

INDIA

Author for correspondence :

S. ANUJA

Department of Horticulture,

Faculty of Agriculture,

Annamalai University,

ANNAMALAI NAGAR (T.N.)

INDIA
THEASIAN JOURNALOF HORTICULTURE

Volume 12 | Issue 2 | December, 2017 |223-226

Visit us -www.researchjournal.co.in

RESEARCH PAPER

DOI : 10.15740/HAS/TAJH/12.2/223-226

\section{Effect of various drying methods on the quality of moringa leaf powder (Moringa oliefera Lam.)}

\section{S. ANUJA AND K. RAMKUMAR ${ }^{1}$}

ABSTRACT : The present study effect of various drying methods on the quality of moringa leaf powder (Moringa oleifera Lam.) was carried out during (Feb.-Dec.) 2016-17 in the post harvest technology lab. Department of Horticulture, Faculty of Agriculture, Annamalai University, Annamalai Nagar. The experiment was laid out in Completely Randomized Block Design with four treatments and five replications. The moringa leaves were dried into powder under four different drying methods viz., $\mathrm{T}_{1}$ (outdoor drying), $\mathrm{T}_{2}$ (indoor drying), $\mathrm{T}_{3}$ (oven drying) and $\mathrm{T}_{4}$ (microwave drying). Among the different treatments $\mathrm{T}_{3}$ (oven drying) recorded high powder yield and also recorded highest value for iron and zinc content. The treatment $\mathrm{T}_{2}$ (indoor drying) recorded high powder yield, besides the same treatment also recorded highest value for beta-carotene and ascorbic acid.

KEY WORDS : Powder, Leaf quality, Vitamins, Minerals, Indoor drying, Outdoor drying

HOW TO CITE THIS ARTICLE : Anuja, S. and Ramkumar, K. (2017). Effect of various drying methods on the quality of moringa leaf powder (Moringa oliefera Lam.). Asian J. Hort., 12(2) : 223-226, DOI : 10.15740/HAS/TAJH/12.2/223-226. 